\title{
A Successful Counter-terrorism Strategy: A Chronicle of India's Counter-terrorism
}

\author{
Sadiki Nyembo Lucien \\ PhD student in the Department of International Relations, the University of Lubumbashi, DR Congo and Head of Works
}

\begin{abstract}
The geopolitical stalemate in which the Democratic Republic of the Congo currently finds itself is becoming more and more worrying. The no-man's-land that this part of the African Great Lakes Region is becoming may be the prelude to a new terrorist dynamic, a rear base and a training center for all those who identify with this strategy. The democratic process which took so much effort to get started risks collapsing under the action of the ADF / NALU, these criminal groups and the DRC is tired of always having to 'start from scratch'. The ADF has been in Beni territory since 1992 at the time of Mobutu. It is not a movement that can be easily dismantled, so these members have forged strong internal ties among the Nande. Above all, it should not be forgotten that the majority of ADF / NALU troops are Nande from Uganda who have converted to Islam. The ADF-Nalu (Allied Democratic Forces - Uganda Liberation Army), are a Ugandan rebellion that is raging in the "Far North" region, the northern part of the province of North Kivu, bordering Uganda, between Lake Albert and Lake Edward, stronghold of the Nande ethnic group. Let us hope that the state of siege decreed by President Félix Antoine TshisekediTshilombo in May 2021 in the provinces of North Kivu and Ituri will bear fruit in the pacification of this part of the DRC. This article claims to demonstrate the hybridism of this movement which is at the crossroads between rebellion and terrorist group.
\end{abstract}

Keywords: ADF / NALU, Terrorist, Democratic Republic of Congo, Uganda, Beni

\section{Introduction}

The specter of terrorism haunts Africa. Mali, Nigeria, Algeria, Somalia, Kenya, Uganda... the development of terrorist and criminal organizations is becoming an increasingly urgent problem to be solved for the African authorities concerned. At a time when the stakes of terrorist action become more and more important, the situation seems paradoxical: on the one hand, the means for an effective and lasting anti-terrorism policy are lacking; on the other hand, criminal groups are becoming more and more powerful and gaining influence at the level of desperate populations who dream of a better tomorrow.

As Abdelkader Abderrahmane, researcher at Conflict Prevention and Risk Analysis' (CPRA) and at the Institute for Security Studies (ISS) (Ethiopia) showed in a recently published paper, Trafficking in arms, drug abuse and money laundering have become commonplace among all of these criminal groups. In addition, "growing links are being woven between the narcoterrorists present in West Africa and European mafia groups such as the Camorra" continues the researcher. Through these cooperations, these groups which are talked about a lot help each other, benefit from their respective expertise and will be able in the short term to transform into hybrid groups as are currently the ADF/NALU which are an example of a group. based on a political ideology which, over time, has mutated into a criminal-narcoterrorist group.

The fall of the Berlin Wall (1989) shattered the existence of Two East-West Blocks and ended the Cold War (Demanet P., 2007: 53). In the Third World countries and particularly in those of the African Great Lakes, democratic trends are born with the establishment of multiparty systems, national conferences, negotiations with the opposition... The acute destabilization of the sub-region begins on $1^{\text {st }}$ October1990, when the Rwandan Patriotic Front (RPF) attacks Rwanda from Uganda. War at the end of which he took power in July
1994, after political agreements, crimes including genocide (Sehene B., 1999: 42). The Great Lakes region today offers the face of a tormented and desolate landscape, conflicts within the states of the region, human rights violations by armed groups and even by regular troops have disrupted the security situation in this region. A certain degradation in the security sector, of Human Rights (Great Lakes Africa, understanding the crisis, RFI (Radio France Internationale) / InstitutPanos Paris).

Originally two Ugandan armed groups fighting against the power embodied by President YoweriMuseveni, the Allied Democratic Forces (ADF) and the National Army of the Liberation of Uganda / NALU) united in 1995, at the instigation of the Zairian and Sudanese secret services, anxious to weaken a common adversary. Settled in the Ruwenzori massif, on the border between the DRC and Uganda, they have never succeeded in establishing themselves in their country of origin, despite several attacks against border towns and attacks in Kampala. However, no large-scale action on Ugandan soil seems to have been recorded there since 2001, although the ADF-NALU still regularly recruit combatants there, which they also do in other East African countries.

It is therefore in Congolese territory, in particular in the north-east of the territory of Beni (North Kivu), around the localities of Eringeti and Oicha and in the area between this axis and the Ugandan border, that the ADF-NALU concentrate their activities. The Ugandan occupation of the region does not seem to have hampered the development of the group. It was especially after the withdrawal of Ugandan forces and the deployment of the FARDC, supported by MONUC, that the ADF-NALU suffered military setbacks, in particular between 2005 and 2007. Following these and negotiations, both with MONUC (current MONUSCO) with the Ugandan government, the NALU branch of the group agreed to dissolve and participate in a DDRRR program, while Kampala recognized, in 2008, a "Kingdom of 
Rwenzururu" to the group. Within its borders the main demand at the basis of the creation of the NALU.

As for the ADF, which seems to have been created in reaction to the repression of Ugandan Muslims undertaken by Museveni after he took power, they do not appear to have the typical profile of a terrorist organization with a radical Islamist ideology attributed to them by the government of Kampala. Even if, since the disappearance of the NALU tendency, all ADF fighters must be of Muslim origin or convert to Islam, they have never expressed the "classic" political objectives of Islamist movements (establishment of Sharia law), a caliphate, etc.) (Jean-Marc Balencie and Arnaud de La Grange, 2001: 1019-1020).

Ugandan ADF rebels have been active in the DRC for several years. They are accused of numerous abuses. The murders of several hundred people are attributed to them in the province of North Kivu. This is how our claim in this reflection is to seek to understand the ADF / NALU movement, for some it is a rebel movement and for others it is a terrorist group.

In the light of all the above, this analysis will seek to answer the following question: This movement at a crossroads, what is its real content? What about the ADF-Nalu for the DRC, will be the first point of this study, for the sake of precision and conciseness, in the second point, it will be a question of the operating methods of the ADF / NALU, the identity of Jamil Mukulu in relation to the ADF movement / NALU, thirdly it will be a question of talking about the UN Forces facing the attacks of the ADF / NALU and finally we will do analyzes on the contribution of the United States against the ADF / NALU.

\section{1) Who are the ADF-Nalu for the DRC?}

ADF-Nalu has between 800 and 1,500 combatants, women and children not included. Based northwest of the Ruwenzori Mountains on the border with Uganda, the militia is an "iron-fisted organization", operating through illegal logging and gold mining, a "network of taxis and mototaxis operating in the towns of Butembo, Beni and Oicha"and"transfers from London, Kenya and Uganda, the money being collected by Congolese intermediaries in Beni and Butembo", according to a report by a United Nations expert group. Butembo, Beni and Oicha are located in the province of North Kivu (Jean-Marc Balencie and Arnaud de La Grange, 2001: 1677).

The group arrived from Uganda in 1995. Attempts to neutralize the ADF-Nalu in 2005 and 2010 were unsuccessful. "This Congolese-Ugandan armed group is showing extraordinary resilience due to its geostrategic position, its integration into the cross-border economy and the corruption of the security forces", the ADF-Nalu have several training camps in the area. Eastern DRC and equipment such as mortars, machine guns and tube grenades. The militia increased its numbers through recruitment campaigns and kidnappings. Between July 2010 and November 2013.

\section{2) Threats from the ADF-Nalu In}

Addition to its growing military power, the ADF-Nalu is seen as a potentially destabilizing force in the Great Lakes region due to its alleged links with radical Islamists. The Ugandan government has long maintained that the group is linked to Al-Qaida and the Somali Islamist movement AlShabab. The majority of Muslims in Congo and Uganda are not politicized, ADF-Nalu leaders in the UK, Congo, Kenya and Sudan adhere to a particularly radical Tabligh Islamist ideology which has led to disputes with other Tablighs in Kampala. The militia has cells outside of Uganda and the DRC and attempts to negotiate amnesty and disarmament have ended in deadlock due to the impossibility of bringing together their various leaders. ADF-Nalu leader Jamil Mukulu, a Christian convert to Islam, has been subject to United Nations sanctions since 2013 (CDi.015 pour sanctions le 13 octobre 2013, en ligne sur le site de l'ONU : 29 Octobre 2014). ADF-Nalu is a hybrid group, not only because of the diverse origins of its members, but also because the militia is the product of twenty years of crossborder life, operating as a guerrilla and often blurring the lines. boundaries between the criminal, the rebel, the citizen, the soldier and the state. Besides, the militia itself is moving. In December 2013, a large number of east-west movements were reported. Women and children dependent on ADFNalu have moved, accompanied by guards, and hid among the local population, they could also carry out asymmetric attacks and ambush unprotected targets, as the militiamen have good sources of intelligence among the population, "and they know where and when to find such and such a person".

\section{3) The fight against the ADF-Nalu in eastern DRC}

The close links between this rebel group and the population, its relations with the Abroad, the support of the warlords and its alliances with other militias in the region make that a clear counterinsurgency strategy is essential: "The question is how to get the population on our side? ". The ADF-Nalu collaborate with various local armed groups and are particularly well integrated within the Muslim population. We must recognize the role of Islam in maintaining peace in the DRC. Indeed, it is only since the assassination of Colonel Mamadou in January 2014 in an ambush set ten kilometers from the city of Beni by the ADF-Nalu that many people realized that the national hero of the Congo was Muslim (Radio France Internationale, January 02, 2014). This is in particular what made him the ideal man to fight against the ADF-Nalu and why his death is a big blow to the population of Beni in general and to his large Muslim community in particular. »

a) ADF / NALU modus operandi - Jamil Mukulu and The ADF Islamist rebellion

What is happening in the Democratic Republic of Congo, in its eastern part, Beni territory in the province of North Kivu, and in the province of Ituri with the repeated massacres of civilian populations by the Ugandan rebels of the ADFNalu, reminds us of the daily ordeal suffered by Nigerians and Cameroonians who are under the terror of the Islamists of the Boko Haram sect. 


\section{b) The ADF / NALU, a well organized militia}

The ADF / NALU are a well organized Ugandan armed group with the hard core leader Jamil Mukulu who was arrested in Tanzania and transferred to Kampala in Uganda (TrésorKibangula, 2015). In the various camps they occupied until the military operations of the Armed Forces of the Democratic Republic of the Congo occasioned by the fact that the Congolese President, Felix Antoine TshisekediTshilombo declared the state of siege in the provinces of North Kivu and Ituri in May 2021 (Radio Télévision Nationale Congolaise, May 2021). The ADFNalu trained, cultivated, prayed, recruited in Uganda and DRC, all in a perfect organization.

Some recruits voluntarily joined the rebellion, sometimes even with their families; for others, they have been presented with economic opportunities; still others were kidnapped and forced to undergo military training. Those who refused were detained and threatened until they gave in. We also discover the Bazana, the kidnapped civilians who became the personal slaves of the leader of the ADF and who were forced to convert to Islam. A method that closely resembles that of BokoHaram.

\section{c) Support networks in the DRC, Uganda and Rwanda}

The group maintained two courts of law, one of which was chaired by Jamil Mukulu himself before his arrest in 2015 . In one of these two courts, refused to convert to Islam, seeking to escape or committing adultery were crimes punishable by death. While they themselves did not hesitate to rape the young girls they took hostage by making them sex slaves. Ultimately, the support network that the ADF has forged in the DRC, Uganda, Rwanda and Great Britain allows them to guarantee themselves better days in terms of financial and material resources such as weapons ... All things being equal in addition, the Ugandan rebels of the ADF-Nalu, it is practically the "Congolese" Boko Haram. Although the UN report does not find any apparent link between the ADF and foreign terrorist organizations such as the Shebab or al-Qaeda, their modus operandi matches those of Boko Haram, but the Congolese government confirms the link of the ADF-NALU with foreign organizations. As specified in the map below:

- Recruitment sites: Uganda, Kenya, Somalia, Democratic Republic of Congo, Burundi, Sudan.

- The camps:transit Chuchubo, Kikingo, Naudi, Kiski, Chad, Mayongose.

- Camps Training: Nadui, makoyova, mwalika.

- The places of supply: Beni, Butembo, Kasindi.

- Local markets: Mavivi, Mbau, Mayimoja, BulongoLume, Eringeti, Mutwanga.

- Ideology: Al Qaida.

- Funding: Qatar Al Qaida, Qatar Al chabab, Sudan.

- Business : Uganda, Beni, Oïcha, Kisangani.

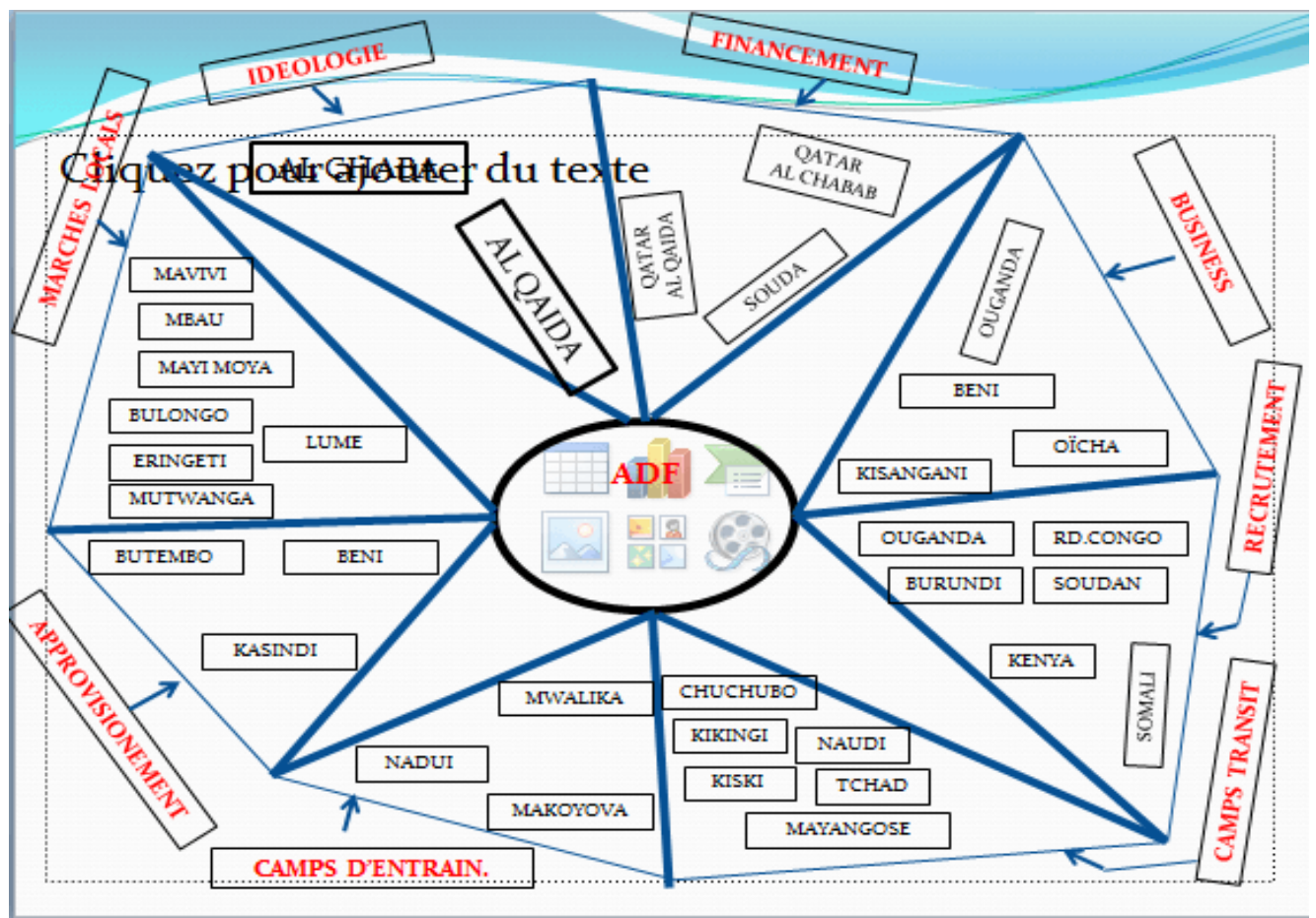

Map No. 1

\section{The ADF network - Source: FARDC document}

a) Whoisresponsible ?

"The ADF are not really what people think they are" "It is not a foreign Islamist organization, but a militia deeply rooted in local society that has links with political and economic actors. While it is true that the ADF are responsible for most of the massacres, it is clear that other groups, such as Congolese soldiers, are also involved.

b) "The limited impact of aid in DRC

The frequency of violence that have occurred over a vast territory - and the fact that some of the attackers spoke Kinyarwanda language that is not generally spoken in this region of the DRC leaves assume that multiple armed groups from a large geographic area are involved. The ADF have been based in the DRC for more than two 
decades. The rebel group forged strong links with local political and economic figures and exploited existing smuggling networks, mainly timber, taking advantage of existing corruption within the FARDC and the local administration. This illicit economy is at the heart of the decades-long violence and instability in the east of the country. The continuing unrest requires a large military presence as the Congolese authorities announced by decreeing a state of siege in May 2021 (constitution of the DRC, 2006).

\section{c) The charges against the ADF / NALU}

Local political leaders describe the rebel organization as an "Islamist militia" and stress its links with extremist networks in the region, notably with Al-Shabab in Somalia and in Kenya while military leaders say it is difficult to defeat ADF rebels due to their guerrilla tactics, it is a terrorist organization that remains difficult to eradicate, although it is no longer as strong as before. However, some civil society leaders and human rights groups believe that the authorities are deliberately exaggerating the role of the ADF in attacks against civilians.

d) The DRC against the ADF / NALU

If the ADF-Nalu fought above all against the Ugandan regime from 1996 to 2001, the movement is still brandished as a threat by Kampala, which regularly accuses it of being linked to the Somali Islamists Shebab. In 2011, members of the Ugandan intelligence service argued that members of the ADF had been trained to make bombs by Somali Islamists. Congolese government spokesperson Lambert Mende also asserted that ADFNalu was associated with the Shebab fighters "and presented it as" a major threat to the security and integrity of the DRC ". "The Shebabs are with us," he insisted, recalling that the presence of Somali mercenaries had already been reported two months ago in the ranks of this movement. ADF-Nalu is the only armed group in eastern Congolese "to be considered a terrorist organization belonging to the Islamist nebula of East Africa." However, the think tank considered that the existence of direct cooperation between the Shebab and the ADF remained "a hypothesis, especially since the Ugandan government is instrumentalizing the terrorist threat for internal and external purposes".

\section{4) The UN forces facing the ADF / NALU}

The UN forces have already been the victim of ADF attacks several times, the most eloquent case is the deadliest attack against MONUSCO in the DRC in Semuliki since its deployment in 1999. But three days after the assault on the base of the United Nations Mission in Congo (Monusco) in Semuliki, the circumstances of the assault are still murky. According to initial information, the ADF attacked the United Nations base. From the start of the attack, the ADF reportedly destroyed the communications post, making the Semuliki base unreachable by the United Nations command. But several questions remain unanswered, in particular on the slowness of the response of the peacekeepers (whose helicopter only intervened the next morning), and of the Congolese soldiers of the FARDC (of which a military post was 500 meters from the base of the Tanzanian peacekeepers). The UN promises an investigation, but the toll is heavy: 15 Tanzanian peacekeepers died and 53 were injured. It should be noted that even the peacekeeping mission is also a victim of ADF attacks at the same level as the civilian population as the FARDC (Christophe R., 2017).

\section{5) The United States against the ADF / NALU}

The United States placed ADF-Nalu on its list of terrorist organizations in 2001, this terrorist group was born in the mid-1990s from the merger of two armed groups opposed to the president Ugandan YoweriMuseveni, in power since 1986. The Nalu component has since disappeared, but the movement retains its appellation of origin. At one time backed by Sudan, the ADF was originally made up mostly of militants from Tabliq, a Muslim missionary movement. Over the years, these fighters have become radicalized. Today only composed of Islamists, the ADF-Nalu has been led since 2007 by Jamil Mukulu before his arrest in Tanzania in 2015, a Christian convert to Islam. The United States placed him on their list of terrorist organizations in 2001 and Jamil Mukulu has been targeted by UN sanctions since 2011 and the European Union since 2012.

Currently, since March 2021, the US State Department states that the ADF and the Islamic State in Central Africa are one structure and therefore the ADF is an affiliated group of the Islamic State. This designation leads to the blocking of the assets of ADF members in the United States and to possible sanctions against any person or entity having relations with the ADF (Le Monde, 2021).

In our opinion, the United States should not limit itself only to pronouncing sanctions against these ADF / NALU in the freezing of assets, but rather to make a large-scale military deployment of NATO as was the case in Afghanistan or in the Sahel like the G5 Sahel for a definitive eradication of terrorism with the multilateralism approach.

\section{Conclusion}

Terrorism destroys all prospects for economic and social development programs in the areas where it proliferates. The situation is such that these criminal organizations are establishing themselves as the main actors and regulators of areas under their control in Africa and the African Great Lakes. Economic flows (legal trade and illegal trafficking) and people (migrations of indigenous populations, movement of tourists and staff of NGOs and actors of the international community) are in the process of being under the complete control of terrorist groups.

If ADF-Nalu fought above all against the Ugandan regime from 1996 to 2001, the movement is still brandished as a threat by Kampala, which regularly accuses it of being linked to Somali Islamists Shebab. In 2011, members of the Ugandan intelligence service argued that members of the ADF had been trained to make bombs by Somali Islamists. For International Crisis Group, ADF-Nalu is the only armed group in eastern Congolese "to be considered a terrorist organization belonging to the Islamist nebula of East Africa. However, the think tank considered that the existence of direct cooperation between the Shebab and the ADF remained "a hypothesis, especially since the Ugandan government is instrumentalizing the terrorist threat for internal and external purposes." Through Sudan, the ADF 
was originally composed mainly of militants from Tabliq, a Muslim missionary movement. Over the years, these fighters have become radicalized. Today composed entirely of Islamists, ADF-Nalu has been led since 2007 by Jamil Mukulu, a Christian convert to Islam. The United States placed him on their list of terrorist organizations in 2001 and Jamil Mukulu has been targeted by UN sanctions since 2011 and the European Union since 2012. Jamil Mukulu has been arrested in Tanzania since 2015 and transferred in Uganda in Kampala where he is on trial. As late as March 2021, the United States Department of State declared that the ADF and the Islamic State in Central Africa are the same structure and therefore the ADF is a group affiliated with the Islamic State. This designation results in the freezing of the assets in the United States of the members of the ADF and possible sanctions against any person or entity having relations with the ADF.

In short, in view of all the above, we can qualify this ADF / NALU movement, a rebel-terrorist movement by the fact that they carry out high-level massacres but without a lesser demand, they operate without means of transport or communication such as vehicle, motorbike, radio, cell phone etc ... But a well organized movement, well financed by some traders from the towns of Beni and Butembo and they sometimes live with the population because they do not wear military uniforms. They speak the Nandé language, a language that is spoken in eastern DRC and neighboring Uganda, so difficult to identify them. If the United States could make a large-scale military deployment of NATO in the East of the DRC as was the case in Afghanistan or at the same time in the Sahel like the G5 Sahel for a definitive eradication of terrorism with the approach multilateralism:

a) A sincere collaboration between the government of the Democratic Republic of Congo and those of neighboring countries including Burundi, Rwanda, Uganda and southern Sudan according to the spirit of the Addis Ababa framework agreement signed on 24 February 2013 especially in point 5 (Within the framework of this agreement, there is a renewed commitment from the states of the African Great Lakes region, in particular in point 5 which stipulates:

b) Not to interfere in the internal affairs of neighboring States;

c) Not to tolerate or provide any assistance or support to armed groups;

d) Respect the legitimate concerns and interests of neighboring states, especially with regard to security issues;

e) Not to host or provide protection of any kind either to persons accused of war crimes, crimes against humanity, acts of genocide or crimes of aggression, or persons under the United Nations sanctions regime).

f) The active involvement of the population against the presence of illegal holders of firearms;

g) A civil disarmament program should adopt a specific approach whereby each holder of firearms should return them at a premium of at least two hundred US dollars and the sites of delivery of these weapons are churches and mosques officially recognized by the government. Government of the Democratic Republic of Congo. This proposal has three objectives, namely:
- The holder of a weapon or war machine should benefit from two hundred American dollars against the deposited weapon.

- The holder will also have benefited from forgiveness from God through pastors, Catholic priests and representatives of Muslim churches to whom he will return the murder weapon.

- When disarmament and demobilization are effective, the eastern part of the Democratic Republic of Congo will be totally pacified.

\section{References}

[1] Accord -cadre d'addisabeba, (2013). Signé le 24 Février 2013, addisabeba.

[2] Afrique des Grands Lacs, comprendre la crise, RFI (Radio France Internationale) / Institut Panos Paris.

[3] Christophe R., (2017). Afrikarabia.

[4] Constitution de la République Démocratique du Congo, (2006). Kinshasa.

[5] Demanet P., (2007). J'ai vécu le mur de Berlin, Bayard jeunesse, Paris.

[6] Guilhaudis, J-F., (2002). Relations internationales contemporains, Litec, Paris.

[7] Hasbi, A., (2004). Théories des relations internationales, l' Harmattan, Paris.

[8] Hassner, P., (2000). La violence et la paix. De la bombe atomique au nettoyage ethnique, Seuil, Paris.

[9] Hassner, P., (2003). La terreur et l'empire, t.2, La violence et la paix, seuil, Paris.

[10] Henninger, L., etWidemann, T., (2013). Comprendre la guerre. Histoire et notions, Perrin, Paris.

[11] Jean-Marc Balencie et Arnaud de La Grange, (2001). Mondes rebelles : L'encyclopédie des acteurs, conflits \& violences politiques, Éditions Michalon, (ISBN 2841861422), Paris.

[12] Jean-Marc Balencie et Arnaud de La Grange, (2005). Les Nouveaux Mondes rebelles, Éditions Michalon, (ISBN 2841862488), Paris.

[13] Le Monde, (2021). «En RDC et au Mozambique, des groupes armés affiliés à l'Etat islamique », Washington.

[14] Meynaud M., (1972). Les groupes de pressions, PUF (Coll.Que sais-je ?), Paris.

[15] Ordonnance $\mathrm{N}^{\circ} 21 / 15$ du 03 mai 2021 portant proclamation de l'état de siège sur une partie du territoire de la République Démocratique du Congo.

[16] Ordonnance $\mathrm{N}^{\circ} 21 / 16$ du 03 mai 2021 portant mesures d'applications de l'état de siège sur une partie du territoire de la République Démocratique du Congo.

[17] Sehene B., (1999). Le piège ethnique, Dagorno, Paris.

[18] Trésor Kibangula, (2015). "Capture en Tanzanie de Jamil Mukulu, chef des rebelles ougandais ADF», Jeune Afrique. 